University of Nebraska - Lincoln

DigitalCommons@University of Nebraska - Lincoln

USDA National Wildlife Research Center - Staff Publications
U.S. Department of Agriculture: Animal and Plant Health Inspection Service

2009

\title{
White-Tailed Deer Herbivory and Timber Harvesting Rates: Implications for Regeneration Success
}

\author{
Brad F. Miller \\ Arkansas Game and Fish Commission
}

Tyler A. Campbell

USDA-APHIS-Wildlife Services, tcampbell@eastfoundation.net

Benjamin R. Laseter

Fish and Wildlife Associates, Inc.

W. Mark Ford

U.S. Army Engineer Research and Development Center, Ecological Resources Branch, Environmental Laboratory

Karl V. Miller

University of Georgia, Athens

Follow this and additional works at: https://digitalcommons.unl.edu/icwdm_usdanwrc

Part of the Environmental Sciences Commons

Miller, Brad F.; Campbell, Tyler A.; Laseter, Benjamin R.; Ford, W. Mark; and Miller, Karl V., "White-Tailed Deer Herbivory and Timber Harvesting Rates: Implications for Regeneration Success" (2009). USDA National Wildlife Research Center - Staff Publications. 945.

https://digitalcommons.unl.edu/icwdm_usdanwrc/945

This Article is brought to you for free and open access by the U.S. Department of Agriculture: Animal and Plant Health Inspection Service at DigitalCommons@University of Nebraska - Lincoln. It has been accepted for inclusion in USDA National Wildlife Research Center - Staff Publications by an authorized administrator of DigitalCommons@University of Nebraska - Lincoln. 


\title{
White-tailed deer herbivory and timber harvesting rates: Implications for regeneration success
}

\author{
Brad F. Miller ${ }^{\mathrm{a}}$, Tyler A. Campbell ${ }^{\mathrm{b}}$, Benjamin R. Laseter ${ }^{\mathrm{c}}$, W. Mark Ford ${ }^{\mathrm{d}}$, Karl V. Miller ${ }^{\mathrm{e}, *}$ \\ a Arkansas Game and Fish Commission, \#2 Natural Resources Drive, Little Rock, AR, USA \\ ${ }^{\mathrm{b}}$ USDA/APHIS/WS/NWRC-Texas Field Station, Texas AEM University-Kingsville, Kingsville, TX, USA \\ ${ }^{\mathrm{c}}$ Fish and Wildife Associates, Inc., P.O. Box 241, Whittier, NC, USA \\ ${ }^{\mathrm{d}}$ Ecological Resources Branch, Environmental Laboratory, U.S. Army Engineer Research and Development Center, 3909 Halls Ferry Road, Vicksburg, MS 39180, USA \\ ${ }^{\mathrm{e}}$ Warnell School of Forestry and Natural Resources, University of Georgia, Athens, GA, USA
}

\section{A R T I C L E I N F O}

Article history:

Received 23 December 2008

Received in revised form 17 April 2009

Accepted 21 May 2009

\section{Keywords:}

Allegheny hardwood-northern hardwood

Browse preferences

Herbivory

Odocoileus virginianus

Regeneration

Timber harvesting

West Virginia

White-tailed deer

\begin{abstract}
A B S T R A C T
Herbivory by white-tailed deer (Odocoileus virginianus) can affect forest regeneration. Typical measures to ensure forest regeneration have included physical barriers or direct manipulation of deer densities. However, altering silvicultural practices to provide abundant deer forage has not been tested thoroughly. We examined browse species preferences and changes in herbivory rates in 1-6 year old regeneration areas from 2001 to 2004 in the central Appalachians on the MeadWestvaco Wildlife and Ecosystem Research Forest in West Virginia. Woody vegetation reached the maximum plot coverage by the 4th growing season. However, the establishment of less abundant woody species, such as northern red oak (Quercus rubra), may be inhibited when browsed greater than or proportionally to occurrence. Herbivory rates declined precipitously as the amount of early successional habitat increased on our study site. We conclude that providing approximately $14 \%$ of an area in well-distributed, even-aged managed forests can have substantial impacts on reducing herbivory rates. However, management practices also should consider harvesting effects on hard mast production, habitat requirements of other species, and hardwood lumber marketability.
\end{abstract}

(c) 2009 Elsevier B.V. All rights reserved.

\section{Introduction}

White-tailed deer primarily alter ecosystem processes by excessive herbivory, although the effect of rubbing trees, trampling, defecation, and urination also can be severe (Danell et al., 2003). Overabundant deer populations may reduce the current abundance and alter the morphology of herbaceous plant species (Augustine and Frelich, 1998; Anderson, 1994) and affect future abundance of browse sensitive species even after reduction of deer densities (Webster et al., 2005). Additionally, changes to forest understories from excessive herbivory can alter abundance and diversity of songbird (McShea and Rappole, 2000; deCalesta, 1994) and small mammal communities (Brooks and Healy, 1988). The effects of excessive herbivory are especially problematic for regenerating forests because long-term successional patterns may be altered (Royo and Carson, 2006; McWilliams et al., 1995; Trumbull et al., 1989; Alverson et al., 1988; Horsley and Marquis, 1983; Marquis, 1981). These impacts can include shifts in woody and herbaceous species composition, reduced stocking, extended

\footnotetext{
* Corresponding author. Tel.: +1 706542 1305; fax: +1 7065428356

E-mail address: KMILLER@warnell.uga.edu (K.V. Miller).
}

rotation lengths, and perhaps entire regeneration failures (Horsley et al., 2003; Tilghman, 1989).

Measures to reduce herbivory by white-tailed deer to ensure regeneration success have involved practices such as reducing deer densities (Behrend et al., 1970; McNulty et al., 1997), exclusion (Brenneman, 1982), or providing abundant summer forage by concentrating silvicultural activities to alleviate browsing pressure within intact forests and regeneration areas (Stout and Lawrence, 1996; Stout et al., 1996; Marquis et al., 1992). However, the interspersion of timber harvests across an area and proportion of the area composed of timber harvests necessary to effectively reduce deer herbivory have not been identified. To date, no research has empirically documented the timber harvest regime necessary to mitigate excessive herbivory by white-tailed deer.

In this study, we investigated the impacts of deer herbivory on regenerating forests in the central Appalachians. A preliminary analysis on our study site investigating the effects of spatial and physical factors on herbivory pressure determined that forest regeneration and forest health were at risk from excessive herbivory (Campbell et al., 2006). We also assessed the relationship between timber harvests and herbivory rates with the goal of developing forest management guidelines to reduce the impacts of herbivory on regenerating and unharvested forests. 


\section{Study area}

Our study was conducted on the MeadWestvaco Wildlife and Ecosystem Research Forest (MWWERF) in southwestern Randolph County, West Virginia. The MWWERF was established by the Westvaco Corporation (now MeadWestvaco) in 1994 to examine the impacts of modern industrial forestry on the landscape and its ecological processes in a central Appalachian environment (Keyser and Ford, 2005). The 3413 ha MWWERF is located in the Unglaciated Allegheny Mountain and Plateau physiographic province $\left(38^{\circ} 42^{\prime} \mathrm{N}\right.$ and $80^{\circ} 3^{\prime} \mathrm{W}$ ). Landscape features consist of broad, plateau-like ridgetops with steep sides and narrow valleys with small, highgradient streams. Elevations range from 700 to $1200 \mathrm{~m}$. The climate is moist and cool with mean annual precipitation in excess of $155 \mathrm{~cm}$ (Strausbaugh and Core, 1977). Soils of the MWWERF are acidic, welldrained Inceptisols (Schuler et al., 2002).

Forests on the MWWERF are naturally regenerated, secondgrowth stands established in the early 1900's following extensive area-wide railroad logging (Clarkston, 1993) or younger stands resulting from harvests of those second-growth forests over the past 20 years. Currently the forests are managed primarily by even-aged harvesting with an 80-100 year rotation length. Harvest areas are well distributed throughout the MWWERF with an average size of 15 ha. Timber harvests implemented in the early 1990's failed to regenerate successfully because of excessive herbivory. The most common forest type is northern hardwoodAllegheny hardwood forests composed of American beech (Fagus grandifolia), yellow birch (Betula alleghaniensis), sugar maple (Acer saccharum), red maple (A. rubrum), black cherry (Prunus serotina), and Fraser magnolia (Magnolia fraseri). Cove hardwoods and mixed-mesophytic forests composed of yellow-poplar (Liriodendron tulipifera), basswood (Tilia americana), sweet birch (Betula lenta), and northern red oak (Quercus rubra) are common at elevations less than $850 \mathrm{~m}$. Elevations over $1000 \mathrm{~m}$ and sheltered riparian areas contain significant amounts of eastern hemlock (Tsuga canadensis) and red spruce (Picea rubens). A shrub layer and understory groundcover is absent in many areas with the exception of rosebay rhododendron (Rhododendron maximum) thickets in higher upland areas and along riparian areas, and thick mats of hay-scented fern (Dennstaedtia punctilobula) in areas where the canopy is interrupted.

Intensive research of the deer population on the MWWERF began in 1999. Population densities on the MWWERF were estimated as $12-20$ deer $/ \mathrm{km}^{2}$ at the beginning of our study (Langdon, 2001). Bucks on the MWWERF experience high annual mortality from hunting, whereas females average approximately 85-90\% annual survival (Campbell et al., 2005). Abomasal parasite counts indicated that the deer population was at or near nutritional carrying capacity (Fisher, 1996).

\section{Methods}

\subsection{Study design}

Beginning in 2001, we collected vegetation and browse data from eight, 1 to 3 years old regeneration sites ranging from 8 to 19 ha in size (Campbell et al., 2006). All regeneration sites were then resampled in 2002 and 2003. In 2004, four of the eight regeneration sites were omitted from additional sampling as most woody browse exceeded herbivory height. During the study period we collected a total of 28 observation-years from regeneration sites ranging in age from 1 to 6 years old.

Within each regeneration site, we established $901 \mathrm{~m}^{2}$ permanent sampling plots. Thirty plots were distributed systematically along the edge of skidder trails at intervals of approximately $120 \mathrm{~m}$. We installed 30 additional plots matched to the plots along skidder trails, but located $5 \mathrm{~m}$ into the regeneration area perpendicular to the skidder trail. Additionally, we established 30 plots in the adjacent unharvested mature forests $\geq 50 \mathrm{~m}$ from the edges of regeneration sites, and distributed systematically in transects parallel to regeneration sites. The mean distance between mature forest plots was $19 \mathrm{~m}$.

We sampled all plots between 15 July and 15 August of each study year. Within each year we sampled plots within \pm 7 days of their original sampling date in 2001 to prevent temporal bias resulting from potential changes in vegetation structure, species composition, or herbivory rates.

\subsection{Plot coverage and herbivory data collection}

We recorded ocular estimates of plot coverage by ferns, forbs, grasses, woody vegetation, and non-vegetation (e.g., rocks, woody debris, litter, and bare ground) within each $1 \mathrm{~m}^{2}$ plot. We obtained coverage estimates from $1.5 \mathrm{~m}$ above each plot, totaling $100 \%$. Mean and standard error plot coverage for each category were calculated for each growing season.

Following Ford et al. (1993), we recorded the total number of browsable units (i.e., twig tips) available of semi-woody (e.g., Rubus spp.) and woody plants $\leq 1.5 \mathrm{~m}$ from the ground. The species of each browsable unit was recorded, and each unit was assigned to a browsed or unbrowsed category. All browsing was assumed to be caused by white-tailed deer because no herbivory by other vertebrates was identified. Only species with yearly averages of $>4000$ browsable units/ha ( $>4$ units $/ 10 \mathrm{~m}^{2}$ ) were included in our analyses.

We calculated percent of available twigs browsed, relative abundance (number of units available for a species/number of units available for all species), and relative use (number of units browsed for a species/number of units browsed for all species) for each species (Strole and Anderson, 1992). To assess preferences of deer for individual plant species, we summed the number of browsable units and the number browsed for each species across all plots within each regeneration area and sampling year. We performed a $Z$-test to determine whether the use of a species was greater than, proportional to, or used less than its proportion of the total number of browsable units available.

\subsection{Scale and distribution of regeneration areas}

We analyzed timber harvest records and stand locations for the MWWERF using MeadWestvaco's Forest Research Information System ${ }^{\mathbb{R}}$ geographical databases. To determine the proportion of the study area $<10$ years of age, we summed the number of hectares harvested in the previous 10 years for each year and then divided by the total property area. To evaluate the impacts of forest management on browsing rates, we calculated a total browsing rate for each year for unharvested and regeneration areas. We calculated total browsing rates $( \pm \mathrm{SE})$ by averaging the mean browsing rates of all stands examined in a sampling year

We used Arcview GIS 3.3 (Environmental Systems Research Institute, 1999) to evaluate the spatial distribution of regeneration sites on the MWWERF. We created a series of buffers around regeneration sites $<10$ years of age (in 2004) with $100 \mathrm{~m}$ distance intervals. The number of hectares within each distance interval was calculated in Arcview using the Xtools extension and divided by the total property area to determine what proportion of the study site was within each distance interval from a regenerating stand.

\subsection{Deer population trends}

We generated a yearly index of deer abundance by recording all incidental observations of deer while traveling on the study site. 
Because of the tendency for deer to form larger social groups and to congregate in localized area during winter, observations during the January-April period were highly variable. Therefore, we calculated the mean monthly number of deer observed per vehicle-mile traveled on the study area during May through December as an index of deer abundance.

\section{Results and discussion}

\subsection{Plot coverage estimates and browse preferences}

Vegetative characteristics of regeneration sites changed across growing seasons (Fig. 1). The non-vegetation category declined from $79 \%$ plot coverage during the 1 st growing season to $41 \%$ plot coverage in the 2nd growing season. Coverage of the woody vegetation category was lowest in the 1 st growing season (15\%), but increased to $48 \%$ and $67 \%$ in the 2 nd and 3rd growing season respectively. Woody vegetation coverage was greatest in the 4 th growing season in which $>74 \%$ of the plot was composed of woody vegetation. After the 4 th growing season, some woody vegetation exceeded the $1.5 \mathrm{~m}$ sampling height, therefore subsequent plot coverage estimates of woody vegetation declined.

Forb coverage was $<1 \%$ in five of six growing seasons. American pokeberry (Phytolacca americana) was the most commonly observed forb species. Pokeberry is a ruderal plant found on disturbed sites such as timber harvests or burned areas, and is commonly consumed by white-tailed deer (Johnson et al., 1995). Mean plot coverage by grass was $<4 \%$ for the six growing seasons examined and apparently had little impact on regeneration success. Fern coverage primarily consisted of hay-scented fern, with lesser amounts $(<10 \%)$ of Christmas fern (Polystichum acrostichoides). Plot coverage estimates were greatest for the fern category in the 5th and 6th growing seasons.

Woody and semi-woody species established rapidly on the regeneration areas. We recorded browsable units from a total of 38 woody, and 4 semi-woody plant species. However, 12 species constituted $85 \%$ of the available browsable units $(238,571$ of $280,764)$ recorded in our study. Nine of the 12 most common species were overstory components prior to timber harvesting. Fire cherry (Prunus pensylvanica), striped maple (Acer pensylvanicum), and blackberry (Rubus spp.) also were common in regeneration areas.

The relative abundance of blackberry was highest across all growing seasons. Black cherry, fire cherry, red maple, and birch (primarily $B$. lenta) were the most common woody species during the 1st growing season. However, black cherry and fire cherry abundance decreased over time, whereas birch abundance

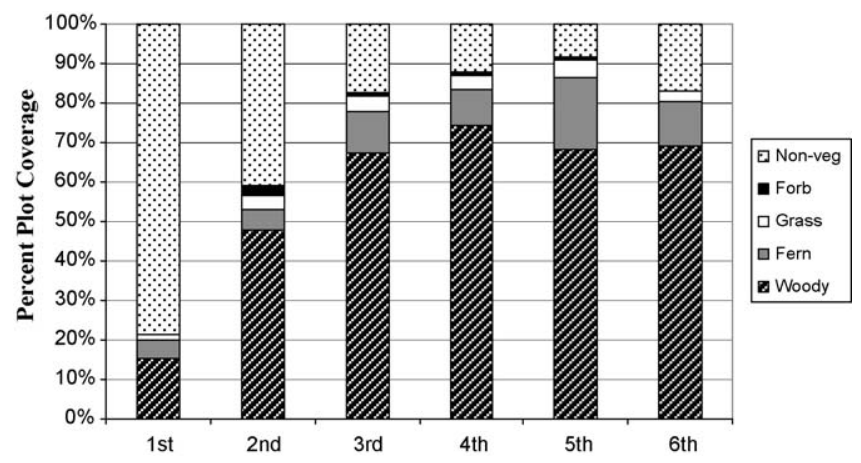

Fig. 1. Average percent of plot coverage by cover type and growing season. Data were collected from harvested sites in late summers of 2001-2004 on the MeadWestvaco Wildlife and Ecosystem Research Forest in Randolph County, West Virginia. Sample sizes by growing season were: $1 \mathrm{st}, n=3 ; 2 \mathrm{nd}, n=5$, 3rd, $n=8$; 4 th, $n=7 ; 5$ th, $n=3 ; 6$ th, $n=2$. increased. American beech was the 9th most abundant species during the 1 st growing season, but increased to the 3rd most abundant species by the 6 th growing season. Northern red oak and witch-hazel (Hamamelis virginiana) were limited in abundance throughout the six growing seasons.

The browse preferences we observed were in general agreement with those reported for other Allegheny and northern hardwood forests. The browsing rates for American beech, red maple, birch, sugar maple, black cherry, yellow-poplar, and striped maple were proportionally less than their occurrence in the browse sample on the MWWERF for over $50 \%$ of the examined site-years (Fig. 2). American beech, black cherry, and striped maple are commonly considered non-preferred species that often increase in abundance or relative to other woody species in areas in response to high deer densities (Horsley et al., 2003; Tilghman, 1989).

The low browsing rates and increase in abundance of American beech and birch across the growing seasons suggests that at least in the short-term, these species will be a substantial component of the forest overstory. In addition, red maple and yellow-poplar may become canopy species based on their low use and moderate abundance. Although striped maple will not become a substantial component of any future overstory, its low relative use may allow it to persist in the under- and mid-story.

Fire cherry, witch-hazel, Fraser magnolia, and northern red oak were browsed in proportion to occurrence in $>50 \%$ of site-years examined (Fig. 2). Previous research on this study area by McGill et al. (2003) investigating the response of fire cherry to prescribed fire, partial canopy removal, and herbivory found that the development of unfenced seedlings was reduced by deer. Northern red oak and witch-hazel were relatively uncommon on our study area. Herbivory impacts may be particularly important to species with lower availability. Because northern red oak is a commercially important species that is difficult to regenerate (Gribko et al., 2002; Buckley et al., 1998), the effects of herbivory are particularly important for this species as well as for wildlife dependent upon the hard mast it produces. An investigation of the relationship between prescribed fire, canopy gaps, and deer herbivory on this study site by Collins and Carson (2003) indicated that herbivory by deer changed the succession process and masked any benefits of fire or increased light availability for establishment of northern red oak seedlings. The low abundance of northern red oak we observed across all growing seasons raises questions regarding its future as an important canopy species on the MWWERF, and perhaps across the central Appalachian region.

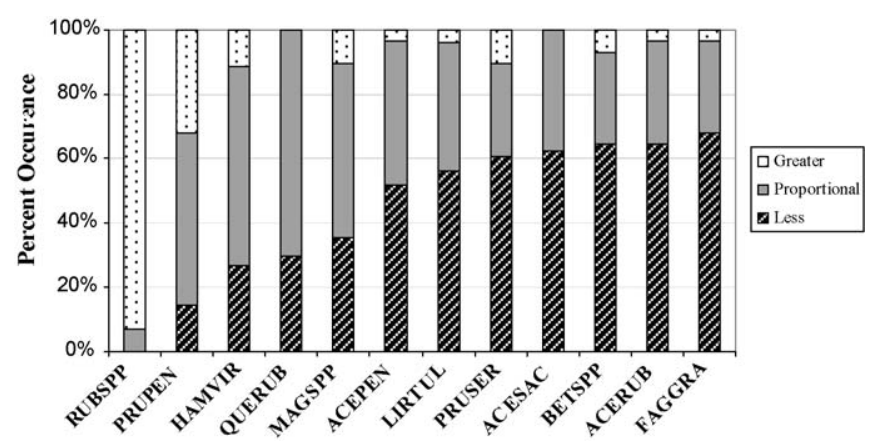

Fig. 2. Percent occurrence by usage category of the 12 most common woody and semi-woody browse species on the MeadWestvaco Wildlife and Ecosystem Research Forest in Randolph County, West Virginia. Data was collected from harvested areas in late summer of $2001(n=8), 2002(n=8), 2003(n=8)$, and 2004 $(n=4)$ ranging in age from 1 to 6 years of growth. Species codes are as follows: RUBSPP, Rubus spp.; PRUPEN, Prunus pensylvanica; HAMVIR, Hamamelis virginiana; QUERUB, Quercus rubra; MAGSPP, Magnolia spp.; ACEPEN, Acer pensylvanicum; LIRTUL, Liriodendron tulipifera; PRUSER, Prunus serotina; ACESAC, Acer saccharum; BETSPP, Betula spp.; ACERUB, Acer rubrum; FAGGRA, Fagus grandifolia. 
Blackberry was browsed proportionally greater than its occurrence in $>92 \%$ of site-years examined (Fig. 2). Additionally blackberry had higher average PATB and RU values than all other species for all growing seasons. The high preference by deer and availability of blackberry may enable it to act as a buffer species to reduce pressure on valuable hardwood species. In Europe, Moser et al. (2006) reported that Rubus spp. protected tree saplings from heavy browsing by roe deer (Capreolus capreolus) by providing attractive forage that reduced dependence on other species. However, the presence of blackberry in regeneration sites in the Appalachians is limited to the 1st few growing seasons (Harlow and Downing, 1970), and extensive levels of Rubus spp. in the understory have been implicated in reducing seedling development in some hardwood stands (Donoso and Nyland, 2006).

\subsection{Deer population trends}

We recorded 15,418 incidental observations of deer during the study period. Between May and December our observation index averaged 0.147 ( $\pm 0.013 \mathrm{SE}$ ) deer per mile traveled. Our index to deer abundance varied little among years and is indicative of a stable deer population, consistent with the estimated $12-20 \mathrm{deer} / \mathrm{km}^{2}$ at the beginning of our study (Langdon, 2001). Additionally, results of a concurrent study of 148 radio-collared adult does (Campbell et al., 2005 ) indicated high annual survival ( $>86 \%$ ), similarly indicative of a stable population density.

\subsection{Timber harvests and browsing rates}

Some past timber harvests implemented in the late 1980's on the MWWERF failed to adequately regenerate as a result of excessive herbivory (P. Keyser, MeadWestvaco, personal communication). This occurred because no other even-aged timber management existed within a 4000 ha matrix of forest at that time, therefore $<0.5 \%$ of the property was in early successional habitat. Anecdotal accounts suggest moderate to high deer densities similar to densities observed by Langdon (2001) have been present on the area for 2 decades (E. Plaugher, MeadWestvaco, personal communication).

The proportion of the study area composed of harvested areas $<10$ years old increased from approximately $8 \%$ to $14 \%$ during the duration of the study (Fig. 3). Overall timber harvest rates were approximately $2 \%$ per year during the course of this study, however harvesting rates of smaller (400-700 ha) portions of the property varied between $1 \%$ and $5 \%$ per year. Mean browsing rates for sample plots in regeneration sites and in unharvested areas declined precipitously as the amount of early successional habitat increased (Fig. 3). Deer use of regeneration areas may decline when regeneration becomes too dense, and/or when forage exceeds the reach of deer (Blymyer and Mosby, 1977). However our average stand age $( \pm$ SE) for the final sampling year (2004) was only $5.0 \pm 0.6$ years of age. Additionally, the decreased browsing rates were observed in adjacent mature forest sites where palatability and vegetation density likely remained constant.

It appears likely that the increased proportion of early successional habitat resulted in an increased ecological carrying capacity on the study area. In fact, increased harvesting intensity has been suggested as a means to reduce overall browsing pressure and ensure regeneration success throughout the central and southern Appalachians (Kalen, 2005; Ford et al., 1993; Marquis et al., 1992). Stout et al. (1996) reported that a combination of a $14 \%$ complete overstory removal, and a 33\% partial cutting was effective for ensuring stand establishment on a 445 ha forested site in the Allegheny hardwood region of northern Pennsylvania. Our results confirm these suggestions but also demonstrate that the addition of partial cuts may not be necessary in all situations. According to our

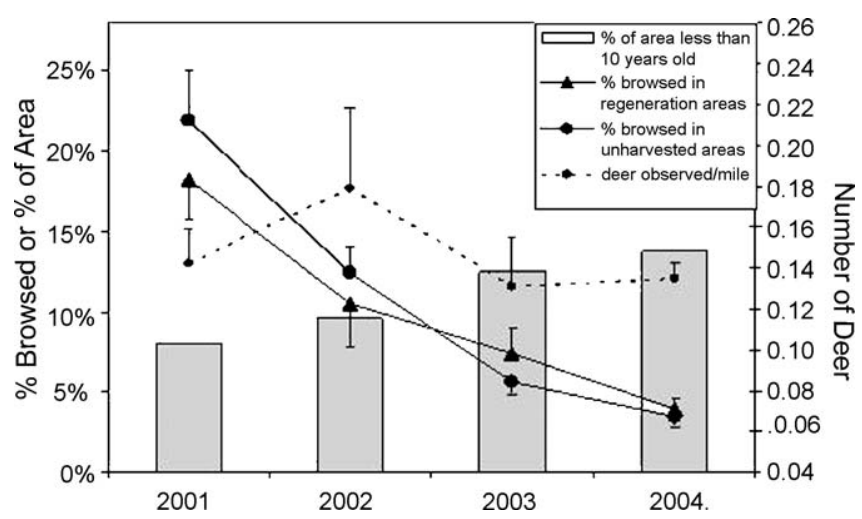

Fig. 3. Percentage of the MeadWestvaco Wildlife and Ecosystem Research Forest in Randolph County, West Virginia less than 10 years old; mean percent browsed $( \pm \mathrm{SE})$ in regeneration areas and unharvested areas, and deer density index (mean number of deer observed per mile driven) from 2001 to 2004. Regeneration site herbivory data were collected from harvested areas in late summer of $2001(n=8)$, $2002(n=8), 2003(n=8)$, and $2004(n=4)$ ranging in age from 1 to 6 years of growth. Unharvested area regeneration data were collected from sample sites adjacent to harvested areas.

data, when approximately $14 \%$ of the area on our study site was composed of stand ages $<10$ years old, the browsing rates dropped to $<5 \%$ for both regeneration areas and mature forests.

The distribution of regeneration areas also is an important determinant of browsing pressure. If timber harvests are

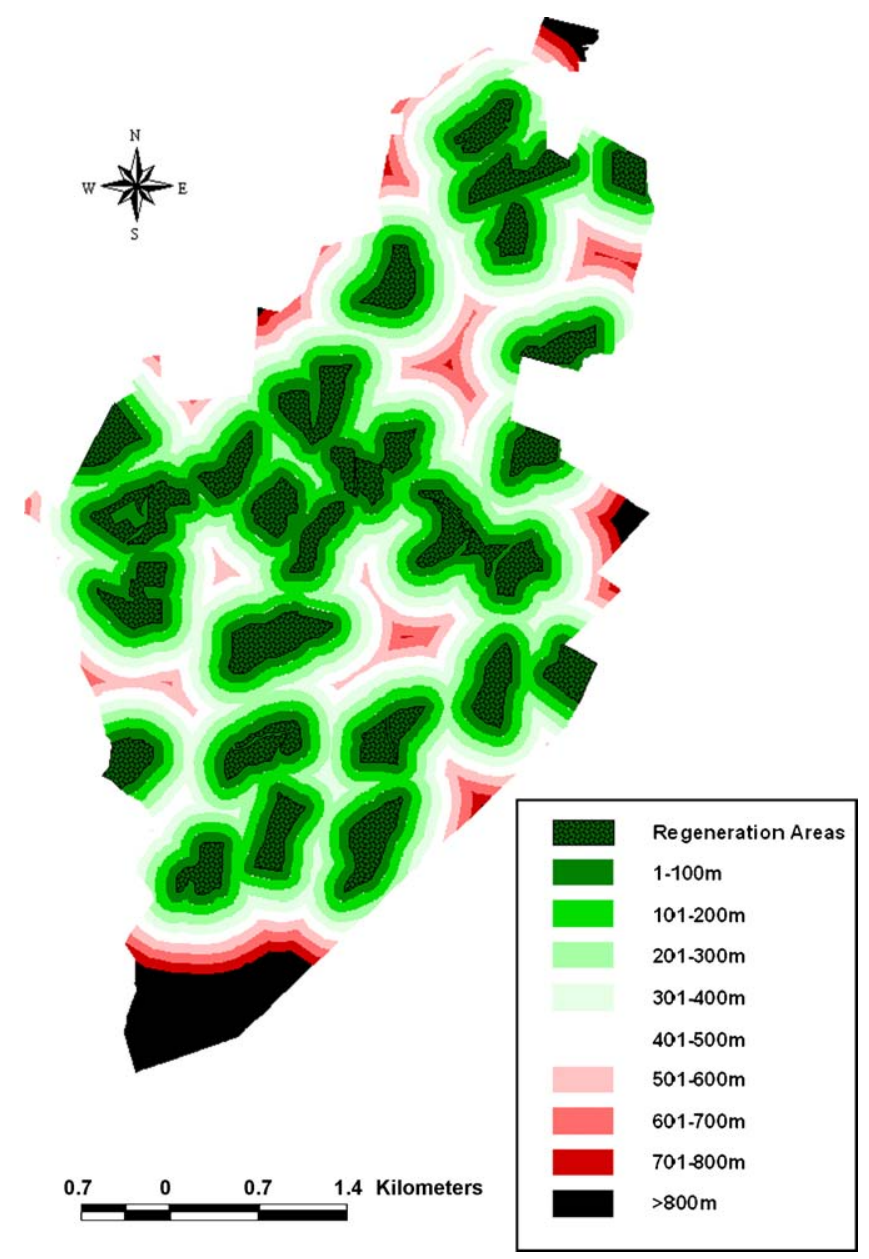

Fig. 4. Timber harvests ( $<10$ years old) in 2004 on the MeadWestvaco Wildlife and Ecosystem Research Forest in Randolph County, West Virginia. Regeneration sites are buffered by $100 \mathrm{~m}$ distance intervals. 
concentrated in a specific area, herbivory impacts in distant areas may not be affected due to philopatric tendencies of deer (Campbell et al., 2004a). Marquis et al. (1992) suggested that the extent of timber harvesting within a $1609 \mathrm{~m}$ radius of a proposed harvest site will determine the impacts of deer herbivory. Augustine and Jordan (1998) found that the intensity of herbivory in forests was inversely related to the availability of agricultural fields within a $1500 \mathrm{~m}$ radius.

By the final year of our study (2004), regeneration sites were well distributed across the study area (Fig. 4). Based on our analysis, $86.5 \%$ of the area was within $500 \mathrm{~m}$ of a regeneration site. Previous investigations of summer home ranges of white-tailed deer on our study site (Campbell et al., 2004b) determined that home range size of male and female deer were 101.2 and 81.5 ha, respectively. Assuming a circular home range, the respective radius for a male and female summer home range is 567 and $509 \mathrm{~m}$. Therefore, despite only 14\% of the MWWERF area comprised of harvested stands, abundant summer food resources were available to the majority of deer on our study site because of the spatial distribution of harvests.

\section{Conclusions}

Results of our species preference analysis were similar to published reports for the region. Blackberry forage was consistently the most preferred and available species in regeneration areas across all examined growing seasons. Based on changes in relative abundance and relative use, we predict that future forests on the MWWERF will be composed of American beech, birch, maples, and yellow-poplar.

Because exclusion fencing or manipulation of deer densities with regulated hunting is not possible for some situations (Curtis et al., 1994; Warren, 1991), providing abundant browse by forest management is a viable option for reducing herbivory. Our results suggest that providing approximately $14 \%$ of an area in welldistributed, early successional or recently regenerated forests can have substantial impacts on herbivory rates. However, the production of increased summer deer food resources may increase carrying capacity and stimulate deer population growth potentially exacerbating deer herbivory (Kramer et al., 2006). Therefore, applications of landscape level forest management must be coupled with sound deer management strategies and with consideration of hard mast retention, habitat requirements of other species, and hardwood lumber marketability. Additional research is necessary to investigate the effects of increased forest harvesting on deer populations.

\section{Acknowledgements}

Financial assistance was provided by the West Virginia Department of Natural Resources, MeadWestvaco, and the USDA National Research Initiative Cooperative Grants program (grant 00-35101-9284 and 03-35101-13719). The comments of J.P. Carroll, C.J. Nairn, and R.J. Warren, improved early versions of this manuscript. We additionally thank the numerous volunteers, technicians, and others who contributed to this research.

\section{References}

Alverson, W.S., Waller, D.M., Solheim, S.L., 1988. Forests too deer: edge effects in northern Wisconsin. Conservation Biology 2, 348-358.

Anderson, R.C., 1994. Height of white-flowered trillium (Trillium grandiflorum) as an index of deer browsing intensity. Ecological Applications 4, 104-109.

Augustine, D.J., Frelich, L.E., 1998. Effects of white-tailed deer on populations of an understory forb in fragmented deciduous forests. Conservation Biology 12, 995-1004.
Augustine, D.J., Jordan, P.A., 1998. Predictors of white-tailed deer grazing intensity in fragmented deciduous forests. Journal of Wildlife Management 62, 1076-1085. Behrend, D.F., Mattfeld, G.F., Tierson, W.C., Wiley III, J.E., 1970. Deer density control for comprehensive forest management. Journal of Forestry 68, 695-700.

Blymyer, M.J., Mosby, H.S., 1977. Deer utilization of clearcuts in southwestern Virginia Southern. Journal of Applied Forestry 1, 10-13.

Brenneman, R., 1982. Electric fencing to prevent deer browsing on hardwood clearcuts. Journal of Forestry 80, 660-661.

Brooks, R.T., Healy, W.M., 1988. Response to small mammal communities to silvicultural treatments in eastern hardwood forests of West Virginia and Massachusetts. In: Szaro, R.C., Severson, K.E., Patton, D.R. (Eds.), Management of Amphibians, Reptiles, and Small Mammals in North America, General Technical Report RM-166, Rocky Mountain Forest Experiment Station. USDA Forest Service, Fort Collins, CO, pp. 313-318.

Buckley, D.S., Sharik, T.L., Isebrands, J.G., 1998. Regeneration of northern red oak: positive and negative effects of competitor removal. Ecology 79, 65-78.

Campbell, T.A., Laseter, B.R., Ford, W.M., Miller, K.V., 2004a. Feasibility of localized management to control white-tailed deer in forest regeneration areas. Wildlife Society Bulletin 32, 1124-1131.

Campbell, T.A., Laseter, B.R., Ford, W.M., Miller, K.V., 2004b. Topographic home ranges of white-tailed deer in the central Appalachians. Southeastern Naturalist 3, 645-652.

Campbell, T.A., Laseter, B.R., Ford, W.M., Miller, K.V., 2005. Population characteristics of a central Appalachian white-tailed deer herd. Wildlife Society Bulletin 33, 212-221.

Campbell, T.A., Laseter, B.R., Ford, W.M., Odom, R.H., Miller, K.V., 2006. Abiotic factors influencing deer browsing in West Virginia. Northern Journal of Applied Forestry 23, 20-26.

Clarkston, R.B., 1993. Destruction of the upland forest by lumbering and fire. In: Stephenson, S.L. (Ed.), Upland Forest of West Virginia. McClain Printing Company, Parsons, WV, pp. 35-46.

Collins, R.J., Carson, W.P., 2003. The fire and oak hypothesis: incorporating the effects of deer browsing and canopy gaps. In: Van Sanbeek, J.W., Dawson, J.O., Ponder, F., Loewenstein, E.F., Fralish, J.S. (Eds.), Proceedings of the 13th Central Hardwood Forest Conference. General Technical Report NC234, North Central Research Station, USDA Forest Service, St. Paul, MN, pp. 44-63.

Curtis, P.D., Fargione, M.J., Richmond, M.E., 1994. Preventing deer damage with barrier, electrical, and behavioral fencing systems. In: Proceedings of the Vertebrate Pest Conference 16. pp. 223-227.

Danell, K., Bergstrom, R., Edenius, L., Ericsson, G., 2003. Ungulates as drivers of tree population dynamics at module and genet levels. Forest Ecology and Management 181, 67-76.

deCalesta, D.S., 1994. Effect of white-tailed deer on songbirds within managed forests in Pennsylvania. Journal of Wildlife Management 58, 711-718.

Donoso, P.J., Nyland, R.D., 2006. Interference to hardwood regeneration in Northeastern North America: the effects of raspberries (Rubus spp.) following clearcutting and shelterwood methods. Northern Journal of Applied Forestry 23, 288-296.

Environmental Systems Research Institute, 1999. ARCVIEW. Version 3.2. Environmental Systems Research Institute, Redlands, CA.

Fisher, J.R., 1996. White-tailed deer herd health check on the Westvaco Wildlife and Ecosystem Research Forest. Final report to the West Virginia Division of Natural Resources. Southeastern Cooperative Wildlife Disease Study, University of Georgia, Athens, USA

Ford, W.M., Johnson, A.S., Hale, P.E., Wentworth, J.M., 1993. Availability and use of spring and summer woody browse by deer in clearcut and uncut forests of the southern Appalachians. Southern Journal of Applied Forestry 17, 116-119.

Gribko, L.S., Schuler, T.M., Ford, W.M., 2002. Biotic and abiotic mechanisms in the establishment of northern red oak seedlings: a review. General Technical Report NE-295, USDA Forest Service, Northeast Research Station, 18 pp.

Harlow, R.F., Downing, R.L., 1970. Deer browsing and hardwood regeneration in the southern Appalachians. Journal of Forestry 68, 298-300.

Horsley, S.B., Marquis, D.A., 1983. Interference by weeds and deer with Allegheny hardwood reproduction. Canadian Journal of Forest Research 13, 61-69.

Horsley, S.B., Stout, S.L., deCalesta, D.S., 2003. White-tailed deer impact on the vegetation dynamics in northern hardwood forest. Ecological Applications 13, 98-118

Johnson, A.S., Hale, P.E., Ford, W.M., Wentworth, J.M., French, J.R., Anderson, O.F., Pullen, G.B., 1995. White-tailed deer foraging in relation to successional stage, overstory type and management of southern Appalachian forests. American Midland Naturalist 133, 18-35.

Kalen, C., 2005. Deer browsing and impact on forest development. Journal of Sustainable Forestry 21, 51-62.

Keyser, P.D., Ford, W.M., 2005. Ten years of research on the MeadWestvaco Wildlife and Ecosystem Research Forest: an annotated bibliography. General Technical Report NE-330, USDA Forest Service, Northeast Research Station, 27 pp.

Kramer, K., Groot Bruinderink, G.W.T.A., Prins, H.T.T., 2006. Spatial interactions between ungulate herbivory and forest management. Forest Ecology and Management 226, 238-247.

Langdon, C.A., 2001. A comparison of white-tailed deer population estimation methods in West Virginia. M.S. Thesis. West Virginia University, Morgantown, WV, p. 119.

Marquis, D.A., 1981. Effect of deer browsing on timber production in Allegheny hardwood forests of northern Pennsylvania. General Technical Report NE-475, USDA Forest Service, Northeast Research Station, 12 pp. 
Marquis, D.A., Ernst, R.L., Stout, S.L., 1992. Prescribing silvicultural treatments in hardwood stands of the Alleghenies (revised). General Technical Report NE-96, USDA Forest Service, Northeast Research Station, 101 pp.

McGill, D.W., Collins, R.J., Carson, W.P., 2003. Response of pin cherry to fire, canopy disturbance, and deer herbivory on the Westvaco Wildlife and Ecosystem Research Forest. In: Van Sambeek, J.W., Dawson, J.O., Ponder, Jr., F., Loewenstein, E.F., Fralish, J.S. (Eds.), Proceedings of the 13th Central Hardwood Forest Conference. General Technical Report NC-234, North Central Research Station, USDA Forest Service, St Paul, MN, pp. 282-290.

McNulty, S.A., Porter, W.F., Mathews, N.E., Hill, J.A., 1997. Localized management for reducing white-tailed deer populations. Wildlife Society Bulletin 25, 265-271.

McShea, W.J., Rappole, J.H., 2000. Managing the abundance and diversity of breeding bird populations through manipulation of deer populations. Conservation Biology 14, 1161-1170.

McWilliams, W.H., Stout, S.L., Bowersox, T.W., McCormick, L.H., 1995. Adequacy of advance tree-seedling regeneration in Pennsylvania's Forests. Northern Journal of Applied Forestry 12, 187-191.

Moser, B., Schutz, M., Hindenlang, K.E., 2006. Importance of alternative food resources for browsing by roe deer on deciduous trees: the role of food availability and species quality. Forest Ecology and Management 226, 248-255.

Royo, A.A., Carson, W.P., 2006. On the formation of dense understory layers in forests worldwide: consequences and implications for forest dynamics, biodiversity, and succession. Canadian Journal of Forest Research 36, 1345-1362.
Schuler, T.M., Ford, W.M., Collins, R.J., 2002. Successional dynamics and restoration of a montane coniferous forest in the central Appalachians, USA. Natural Areas Journal 22, 88-98.

Stout, S.L., deCalesta, D.S., DeMarco, L., 1996. Can silviculture change deer impact? In: Proceeding of the 1995 Society of American Foresters Convention, Bethesda, MD, pp. 437-438.

Stout, S.L., Lawrence, L., 1996. Deer in Allegheny Plateau forests: learning the lessons of scale. In: Proceeding of the 1995 Society of American Foresters Convention, Bethesda, MD, pp. 92-98.

Strausbaugh, P.D., Core, E.L., 1977. Flora of West Virginia. Seneca Books, Gainesville, WV, 1079 pp.

Strole, T.A., Anderson, R.C., 1992. White-tailed deer browsing: species preferences and implications for central Illinois forests. Natural Areas Journal 12, 139-144.

Tilghman, N.G., 1989. Impacts of white-tailed deer on forest regeneration in Northwestern Pennsylvania. Journal of Wildlife Management 53, 524-532.

Trumbull, V.L., Zielinski, E.J., Aharrah, E.C., 1989. The impact of deer browsing on the Allegheny forest type. Northern Journal of Applied Forestry 6, 162-165.

Warren, R.J., 1991. Ecological justification for controlling deer populations in eastern national parks. In: Transactions of the North American Wildlife and Natural Resources Conference 56. pp. 56-66.

Webster, C.R., Jenkins, M.A., Rock, J.H., 2005. Long-term response of spring flora to chronic herbivory and deer exclusion in Great Smoky Mountains National Park, USA. Biological Conservation 125, 297-307. 